\title{
PEMAKZULAN PRESIDEN REPUBLIK INDONESIA PASCA AMANDEMEN UUD 1945
}

(Impeachment of President of the Republic of Indonesia after the amendment of Constitution)

\author{
Eko Noer Kristiyanto \\ Badan Pembinaan Hukum Nasional - Kementerian Hukum dan HAM RI \\ Jalan Mayjen Sutoyo Nomor 10 Jakarta Timur \\ Email: tigers_nova@yahoo.com
}

Naskah diterima: 14 November 2013; revisi: 18 November 2013; disetujui: 17 Desember 2013

\begin{abstract}
Abstrak
Dinamika ketatanegaraan yang secara nyata menunjukkan korelasi antara dimensi hukum dan politik adalah proses pemberhentian presiden sebagai kepala negara. UUD 1945 hasil amandemen telah memuat secara khusus ketentuanketentuan mengenai pemberhentian presiden sebagai kepala negara, hal ini tentunya sangat baik dan jika kita mengacu kepada prinsip negara hukum yang dicita-citakan. Tulisan ini menjelaskan bahwa pengaturan mengenai pemakzulan dalam konstitusi adalah hal yang tepat dan sangat sesuai dengan prinsip negara hukum dan demokrasi, dan merupakan konsekuensi logis ketika kita ingin mewujudkan suatu pemerintahan yang stabil sesuai dengan praktik sistem pemerintahan presidensial. Diharapkan pemakzulan presiden yang hanya didasarkan alasan politis seperti terjadi dimasa lalu tidak akan terulang lagi. Meski demikian, aspek substansi dan mekanisme terkait pemakzulan yang kini sudah jauh lebih baik dengan pengaturan yang lebih jelas dan lengkap itu, kiranya tetap perlu terus dikaji secara dialektika akademis, utamanya terkait mengenai peran dari MPR dalam putusan akhir proses pemakzulan. Karena dalam suatu negara hukum, maka putusan terkuat, yang bersifat akhir dan mengikat adalah putusan hukum, yang dalam proses pemakzulan dikeluarkan oleh proses peradilan hukum di Mahkamah Konstitusi.
\end{abstract}

Kata Kunci: pemakzulan, presidensial, negara hukum, demokrasi, konstitusi

\section{Abstract}

The dynamic of constitutional that clearly shows the correlation between the legal and the political dimension is the impeachment of the president as head of state. Amendments of Indonesia constitution have specifically contain provisions regarding impeachment of the president as head of state, it is certainly very good and if we refer to the principle of state of law. This paper explains that the regulation of impeachment in the constitution is the right thing and is in accordance with the rule of law and democracy, and is the logical consequence when we want to realize a stable government in accordance with the practice of presidential system. Expected presidential impeachment based solely political reasons such as occurred in the past will not be repeated again. However, aspects of the substance and impeachment mechanism better, would still need to be studied in the dialectic of academic, primarily related to the role of the People's Consultative Assembly (MPR) in the final decision process of impeachment. Because in a state of law, the judicial decision shall be final and binding.

Keywords: impeachment, presidential, state of law, democracy, constitution 


\section{A. Pendahuluan}

Salah satu dinamika ketatanegaraan yang secara nyata menunjukkan adanya keterkaitan erat antara proses hukum dan proses politik adalah proses pemberhentian presiden sebagai kepala negara. Proses pemberhentian presiden dikenal dalam praktik ketatanegaraan diberbagai negara, secara istilah proses ketatanegaraan ini disebut sebagai pemakzulan, namun banyak nomenklatur dan pemberitaan yang menyebutnya sebagai impeachment. Impeachment, adalah kata yang biasa ditujukan kepada seorang kepala negara, dalam hal ini presiden. Kata impeachment sendiri dalam bahasa Indonesia dapat kita alih bahasakan sebagai pemakzulan, dakwaan atau tuduhan Impeachment, berasal dari kata aktif "to impeach" yang artinya adalah meminta pertanggungjawaban. Jika tuntutannya terbukti maka konsekuensinya adalah "removal from office" atau pemberhentian dari jabatan. Dalam artian bahwa impeachment sendiri bukanlah hukumannya namun bagian atau tahapan dari sebuah proses yang bersifat penuntutan atas dasar pelanggaran hukum yang dilakukan oleh presiden. ${ }^{1}$

Impeachment adalah suatu proses dakwaan yang diajukan oleh cabang legislatif suatu pemerintahan terhadap pejabat sipil. Secara hukum istilah impeachment diterapkan hanya untuk dakwaan. Dalam penggunaaan yang umum, hal tersebut mencakup persidangan terhadap terdakwa yang dilakukan cabang legislatif yang lebih tinggi. Seperti yang terjadi di Amerika dan Inggris, oleh pengadilan seperti di Jerman, Belgia, Perancis, India, dan Italia, atau oleh gabungan keduanya sebagaimana dilakukan oleh negara-negara bagian di Amerika Serikat. ${ }^{2}$ Berdasarkan pandangan tersebut, dalam arti sempit impeachment tidak sama dengan pemakzulan, karena impeachment hanya salah satu tahap dari proses pemakzulan. ${ }^{3}$ Oleh karena yang akan dibicarakan dalam tulisan ini adalah proses pemberhentian presiden dalam konteks keseluruhan hingga akhirnya berhenti, maka kata yang digunakan sebagai judul tulisan adalah pemakzulan, bukan impeachment yang hanya terbatas pada proses dakwaan/tuduhan saja dan belum tentu yang presiden yang di impeach itu akan berhenti dari jabatannya sebagai presiden.

Dalam konteks sejarah Indonesia, telah terjadi dua kali pemberhentian presiden sebelum masa jabatannya berakhir, yaitu pada kasus mantan presiden Soekarno dan mantan presiden Abdurrahman Wahid. Banyak pihak menilai proses pemberhentian keduanya inkonstitusional dan hanya dipengaruhi oleh kekuatan politik semata tanpa ada proses hukum yang dilalui, tentunya hal ini cukup mengusik penulis yang hingga saat ini masih meyakini dengan teguh bahwa Negara Kesatuan Republik Indonesia adalah negara yang berdasarkan hukum sehingga seluruh proses ketatanegaraan terutama yang termasuk kejadian luar biasa seperti pemakzulan presiden haruslah diatur secara jelas oleh konstitusi sebagai pedoman tertinggi dalam mekanisme ketatanegaraan. 
Berbeda dengan Undang-Undang Dasar 1945 (UUD 1945) yang asli, UUD 1945 hasil amandemen telah memuat secara khusus ketentuan-ketentuan mengenai pemberhentian presiden sebagai kepala negara, hal ini tentunya sangat baik dan jika kita mengacu kepada prinsip negara hukum (rechtstaat) yang dicita-citakan, namun apa benar pengaturan pemakzulan presiden dalam UUD 1945 pasca amandemen telah menjadikan proses pemberhentian kepala negara di Indonesia menjadi ideal, mengingat faktor politik adalah hal yang sangat berpengaruh dalam proses ini. Penulis berusaha mencari jawaban, bagaimana proses hukum dan proses politik terjadi dalam mekanisme pemakzulan presiden di Indonesia setelah perubahan UUD 1945, dan apakah ketentuan dalam pasal tentang pemakzulan presiden dalam UUD 1945 pasca amandemen yang berlaku sekarang perlu dipertahankan, atau justru dianggap tidak penting?

\section{B. Permasalahan}

1. Bagaimana proses politik dan proses hukum yang terjadi dalam proses pemakzulan presiden di Indonesia setelah perubahan UUD 1945?

2. Apakah ketentuan khusus mengenai pemakzulan presiden dalam UUD 1945 perubahan perlu dipertahankan atau tidak?

\section{Metode Penelitian}

Metode penelitian yang digunakan dalam penulisan ini adalah metode penelitian hukum normatif, metode penelitian hukum normatif pada dasarnya meneliti kaidah-kaidah hukum dan asas-asas hukum, ${ }^{4}$ menelaah permasalahan dengan berpedoman pada data sekunder yaitu: bahan hukum primer, sekunder dan tersier. Bahan hukum primer yang dimaksud adalah Undang-Undang Dasar 1945, undangundang, peraturan pemerintah, dan peraturan perundang-undangan lain yang berkaitan dengan judul penelitian.

Bahan hukum sekunder yang dimaksud adalah doktrin, ajaran para ahli, hasil karyailmiah para ahli, berita-berita dan hasil wawancara pihak terkait yang diperoleh dari surat kabar serta situs-situs internet yang relevan dengan judul penelitian.

Data di atas dikumpulkan melalui studi kepustakaan (library research), penelurusan melalui media internet (online research), dalam hal ini penulis menitikberatkan dalam konteks peraturan dalam UUD 1945 yang secara eksplisit mengatur proses pemberhentian presiden, hal ini harus dijelaskan dengan tegas dalam konstitusi negara ${ }^{5}$, Pemakzulan presiden merupakan kejadian luar biasa dan istimewa karena ditujukan kepada warga Negara yang menduduki jabatan istimewa pula yaitu sebagai Presiden. Proses peradilannya pun dilakukan melalui forum khusus yang pada pokoknya

4 Bagir Manan, "Penelitian Terapan di Bidang Hukum" (makalah, disampaikan pada Lokakarya Peranan Naskah Akademis Dalam Penyusunan Peraturan Perundang-undangan, BPHN, Jakarta, 9-11 November 1993), hlm.7. Soerjono Soekanto dan Sri Mamudji menyatakan bahwa penelitian hukum normatif atau penelitian hukum kepustakaan merupakan penelitian hukum yang dilakukan dengan cara meneliti bahan pustaka atau data sekunder belaka yaitu dengan cara menelaah permasalahan dengan berpedoman pada data sekunder.

5 Sri Soemantri mengatakan bahwa konstitusi memuat susunan struktur ketatanegaraan termasuk pembagian tugas lembaga negara dan batas-batas kekuasaannya. 
merupakan "forum previligiatum" atau forum istimewa bagi warga negara yang menduduki jabatan tertentu. Forum previligiatum adalah konsep pemberhentian pejabat tinggi negara (termasuk presiden) melalui mekanisme peradilan khusus. Artinya presiden yang dianggap melanggar hukum diberhentikan melalui mekanisme pengadilan yang dipercepat tanpa melalui jenjang pemeriksaan pengadilan konvensional dari tingkat bawah. ${ }^{6}$ Bagir Manan menyebut keseluruhan proses pemakzulan ini sebagai peradilan tata negara. ${ }^{7}$

Penelitian difokuskan untuk membandingkan pengaturan dan mekanisme pemberhentian presiden yang dilakukan/dapat dilakukan pada masa berlakunya UUD 1945 dan masa berlakunya UUD 1945 pasca amandemen. Pemakzulan yang telah terjadi kepada dua orang kepala negara di Indonesia dinilai begitu sarat dengan aroma politis dan tidak mencerminkan proses bernegara sebagaimana prinsip negara hukum yang selama ini dicita-citakan. Sehingga salah satu pembeda yang paling penting antara UUD sebelum perubahan dan UUD setelah perubahan adalah tentang diaturnya mekanisme pemberhentian presiden secara eksplisit dalam UUD perubahan. ${ }^{8}$

\section{Pembahasan}

\section{Indonesia sebagai Negara Hukum dan Demokrasi $^{9}$}

Indonesia adalah negara hukum. Hal ini sebagaimana ditegaskan dalam Pasal 1 ayat (3) Undang-Undang Dasar Negara Republik Indonesia Tahun 1945. ${ }^{10}$ Dengan demikian, negara wajib menjunjung supremasi hukum (supremacy of the law) sebagai salah satu sendi politik bernegara, disamping sendisendi demokrasi, sendi keadilan sosial dan lain-lain sebagaimana diamanatkan oleh Konstitusi. Negara hukum seringkali diistilahkan sebagai rechstaat oleh ahli-ahli hukum Eropa Barat Kontinental seperti Immanuel Kant dan Friedrich Julius Stahl pada abad 19 dan permulaan abad $20 .^{11}$

Sebagaimana dikemukakan oleh Bagir Manan dalam bukunya bahwa jika ditinjau dari aspek penegakan hukum (law enforcement), negara hukum menghendaki suatu kekuasaan peradilan yang merdeka, yang tidak dipengaruhi oleh kekuatan-kekuatan lain yang akan menyimpangkan hakim dari kewajiban menegakkan hukum, keadilan, dan kebenaran. ${ }^{12}$ Pedoman dan acuan terpenting praktik bernegara dalam negara hukum adalah bagaimana mengimplementasikan konstitusi 
dalam konteks hubungan antara lembagalembaga negara yang ada, salah satunya adalah presiden termasuk pula menyangkut bagaimana proses pemberhentiannya. Keberadaan konstitusi berkembang dari ide pemerintahan yang terbatas (limited government) ${ }^{13}$ atau paham konstitusionalisme agar kekuasan tidak disalahgunakan. ${ }^{14}$ Menjadi perhatian utama dalam paham konstitusionalisme, bahwa walaupun pemerintah (dalam arti luas) dibentuk untuk melayani kepentingan orang banyak, namun diperlukan pembatasan kekuasaan ketika menjalankan kekuasaan.

Konstitusi memuat pembagian kekuasaan dalam bentuk pembentukan lembaga-lembaga negara dan batas-batas kekuasaannya. Sri Soemantri menegaskan bahwa materi muatan konstitusi, yaitu: adanya jaminan terhadap hak-hak asasi dan warga negara; ditetapkannya susunan ketatanegaraan yang bersifat fundamental; adanya pembagian dan pembatasan tugas ketatanegaraan yang juga bersifat fundamental. ${ }^{15}$ Secara umum, konstitusi setiap negara terdiri dari (materi muatan), bagian pertama berkaitan dengan struktur pemerintahan; dan bagian kedua, berkaitan dengan jaminan hak-hak asasi manusia khususnya kepada warga negara.

\section{Sistem Presidensial}

Impeachment dikenal dalam negara yang menerapkan sistem pemerintahan presidensial, sebagai penyeimbang dalam sistem presidensial. Sidang impeachment merupakan sidang politik, sehingga padanya tidak dikenal sanksi pidana denda maupun kurungan. Namun demikian, setelah di-impeach, seorang pejabat negara dapat disidangkan kembali dalam peradilan umum dengan proses penuntutan yang dimulai dari awal sesuai dengan dakwaan yang ditujukan atasnya. Proses impeachment merupakan salah satu kekuasaan yang dipegang oleh lembaga legislatif sebagai bentuk dari fungsi kontrol parlemen atas tindak-tanduk setiap pejabat publik yang telah diberikan amanat oleh rakyat untuk menjalankan tugas dan kewajibannya. Apabila pejabat publik tersebut melakukan pelanggaran pada masa jabatannya dalam aturan konstitusi maupun hukum positif, maka terhadap yang bersangkutan dapat dihadapkan pada proses impeachment yang mengarah pada pemecatan yang bersangkutan dari jabatannya.

Sistem presidensial merupakan sistem pemerintahan yang terpusat pada jabatan presiden sebagai kepala pemerintahan (head of government) dan kepala negara (head of state). Dalam sistem parlementer, jabatan kepala negara (head of state) dan kepala pemerintahan (head of government) itu dibedakan dan dipisahkan satu sama lain. Kedua jabatan kepala negara dan kepala pemerintahan itu, pada hakikatnya, sama-sama merupakan cabang kekuasaan eksekutif. Oleh C. F. Strong, kedua jabatan eksekutif ini dibedakan antara pengertian nominal executive dan real executive. Kepala negara disebut oleh C.F. Strong sebagai nominal executive, sedangkan kepala pemerintahan disebutnya real executive. ${ }^{16}$ Eksekutif tunggal

K.C. Wheare, Modern Constitution (London: Oxford University Press, 1975), hlm. 7.

14 Miriam Budiarjo, Dasar-Dasar Ilmu Politik. (Jakarta: PT. Gramedia Pustaka Utama, 1993), hlm. 57. Lord Acton mengatakan: "power tends to corrupt, absolute power corrupt absolutely". Bahwa kekuasaan itu cenderung disalahgunakan, dan kekuasaan yang absolut sudah pasti akan disalahgunakan.

15 Sri Soemantri, Prosedur dan Sistem Perubahan Konstitusi, edisi revisi (Bandung: Alumni, 2006), hlm. 1.

16 CF Strong, Modern Political Constitutions (London: Sidgwick, 1960). 
dalam sistem pemerintahan presidensial tidak bertanggungjawab kepada Badan Perwakilan Rakyat, tetapi langsung kepada rakyat karena dipilih langsung atau dipilih melalui badan pemilih (electoral college). ${ }^{17}$ Dalam sistem presidensial ini kedudukan antara eksekutif (presiden) dan legislatif (DPR) adalah sama kuat. ${ }^{18}$

UUD 1945 menganut sistem presidensial, salah satu keuntungan dari sistem presidensial adalah, bahwa pemerintahanuntukjangka waktu yang ditentukan itu stabil, ini berbeda dengan sistem parlementer dimana pemerintahan relatif mudah untuk dijatuhkan. Kelemahannya adalah bahwa apa yang ditetapkan sebagai tujuan negara menurut eksekutif (presiden) bisa berbeda dengan pendapat legislatif (DPR), hal seperti inilah yang dapat membuat perselisihan besar sehingga memicu dimulainya mekanisme impeachment. ${ }^{19}$

\section{Sejarah Pemakzulan di Indonesia}

Di Indonesia telah terjadi dua kali peristiwa pemberhentian presiden sebelum masa jabatannya berakhir, meskipun tidak secara eksplisit menyebut kata impeachment ataupun pemakzulan, namun secara dinamika ketatanegaraan dapat dikatakan bahwa peristiwa tersebut adalah pemakzulan.

Sebelum perubahan UUD 1945 Indonesia memang tidak mengenal secara eksplisit dan redaksional mengenai kata impeachment, baik dalam konstitusi maupun peraturan perundangundangan yang berlaku, namun mengenal ketentuan mengenai pemberhentian presiden dan/atau wakil presiden, maka kemudian proses terkait pemberhentian presiden dan/ atau wakilnya lah yang kita sebut sebagai impeachment dalam konteks ketatanegaraan Indonesia.

Sepanjang perjalanansejarahketatanegaraan Indonesia telah terjadi pemberhentian presiden sebanyak dua kali yaitu pada masa Presiden Soekarno dan Presiden Abdurrahman Wahid. Hal yang menjadi penyebab terjadinya peristiwa ketatanegaraan tersebut jalah sengketa antara dua lembaga negara yakni DPR yang di satu sisi berhadap-hadapan dengan Presiden di sisi yang lain.

\section{a. Presiden Soekarno}

Sejarah mencatat perseteruan antara DPR dengan Presiden di Indonesia yang pertama kali terjadi adalah pada tahun 1966-1967 dimana Presiden Soekarno memberi progress report kepada MPRS. Secara de facto, perkembangan situasi kenegaraan yang terjadi pada waktu itu memang tidak memihak kepada Presiden Soekarno. Dengan kata lain, secara politis dukungan kepada Presiden Soekarno sangat kecil atau hampir habis. Sehingga dalam Sidang Istimewa MPRS tahun 1967, MPRS mencabut kekuasaan pemerintahan negara dari tangan Presiden Soekarno dengan Ketetapan MPRS No. XXXIII/MPRS/1967, hanya dengan alasan mayoritas anggota MPRS tidak menerima pidato pertanggungjawaban Presiden Soekarno, yang dinamainya Nawaksara, mengenai sebab-sebab 
terjadinya peristiwa G 30S/PKI. ${ }^{20}$ Meskipun tidak ada aturan yang jelas mengenai impeachment pada saat itu, dan karenanya penarikan mandat oleh MPRS terhadap Presiden Soekarno sangat terbuka untuk diperdebatkan, jatuhnya Presiden Soekarno menunjukkan bahwa dalam praktik ketatanegaraan Indonesia pernah terjadi pemakzulan terhadap presiden. ${ }^{21}$

\section{b. Presiden Abdurrahman Wahid}

Perseteruan antara DPR dengan Presiden yang kedua kalinya terjadi pada tahun 2001 dimana antara DPR hasil Pemilihan Umum tahun 1999 dengan Presiden Abdurrahman Wahid yang diangkat oleh MPR hasil Pemilu 1999 mengalami perseteruan yang berlanjut mosi tidak percaya DPR atas Presiden Abdurrahman Wahid. Dengan argumen Presiden Abdurrahman Wahid dinilai telah melakukan pelanggaran hukum dan konstitusi, para anggota DPR kemudian mengajukan usulan memorandum yang memang diatur oleh TAP MPR Nomor III/ MPR/1978. Memorandum kepada presiden itu untuk meminta keterangan dalam kasus Buloggate dan Bruneigate. Keterangan yang disampaikan oleh presiden dalam Memorandum Pertama ditolak oleh mayoritas anggota DPR yang berakibat harus dilakukan Memorandum Kedua. Namun pada Memorandum Kedua ini keterangan presiden tetap ditolak oleh mayoritas anggota DPR. Dalam situasi yang seperti itu, konflik politik antara presiden dan DPR menjadi tajam. Dalam posisi politik yang semakin terjepit dan kelanjutan kekuasaannya terancam, Presiden Abdurrahman Wahid pun lalu mengambil langkah politik mengeluarkan Dekrit Presiden yang menyatakan membubarkan parlemen dan akan segera melakukan pemilihan umum. Langkah politik presiden itu dibalas oleh mayoritas anggota DPR dengan tidak mengakui Dekrit Presiden tersebut dan kemudian melakukan Memorandum Ketiga yang dipercepat dengan agenda mencabut mandat terhadap presiden (impeachment) melalui Sidang Istimewa MPR tahun 2001 dengan Ketetapan MPR No. III/MPR/2001. ${ }^{22}$

\section{Pengaturan Pemakzulan menurut UUD 1945 hasil amandemen}

Amandemen ketiga UUD 1945 telah memasukkan pasal-pasal mengenai proses pemberhentian presiden yaitu pasal 7A dan 7B. Proses Impeachment terhadap presiden di republik ini dimulai ketika DPR menggunakan hak bertanya yang merupakan fungsi pengawasan seperti diatur di pasal 20A ayat (1), yang berkorelasi dengan pasal 7B ayat (2) Undang-Undang-Undang Dasar 1945. Kemudian usulan pemberhentian tersebut diajukan ke Mahkamah Konstitusi (MK) untuk diproses dan diputuskan bahwa Presiden dan/ atau Wakil Presiden terbukti bersalah atau tidak bersalah dengan dasar Pasal 7B ayat (4) dan ayat (5). Putusan MK itu diteruskan ke DPR untuk diusulkan sidang kepada MPR dan dalam rapat paripurna MPR dinyatakan presiden dan/atau wakil presiden berhenti atau tidak berhenti dari jabatannya.

Tempo, Sukarno-Paradoks Revolusi Indonesia, Seri Buku Tempo (Jakarta: Kepustakaan Populer Gramedia, 2010), hlm. 25.

21 Yudho Winarno. dkk. Mekanisme Impeachment dan Hukum Acara Mahkamah Konstitusi (Jakarta: Pusat Penelitian dan Pengkajian Mahkamah Konstitusi, 2005).

22 Ibid. 
Dalam Undang-Undang Dasar 1945 hasil perubahan Pasal 7A, impeachment dapat dilakukan terhadap presiden dan/atau wakil presiden berdasarkan alasan-alasan, yaitu: a) Telah melakukan pelanggaran hukum berupa pengkhianatan terhadap Negara; b) Telah melakukan korupsi; c) Telah melakukan penyuapan; d) Telah melakukan tindak pidana berat lainnya; e) Telah melakukan perbuatan tercela; dan f) Telah terbukti tidak lagi memenuhi syarat sebagai presiden dan/atau wakil presiden.

Definisi atas alasan impeachment tersebut di Indonesia dijabarkan dalam Pasal 10 ayat (3) Undang-Undang Nomor 24 Tahun 2003 Tentang Mahkamah Konstitusi. Yang disebut "tindak pidana berat lainnya" adalah tindak pidana yang diancam dengan pidana penjara 5 (lima) tahun atau lebih. Alasanalasan pidana dalam proses pemberhentian presiden menurut ketentuan UUD 1945 sesuai pula dengan apa yang pernah dikatakan Sri Soemantri mengenai impeachment, yaitu suatu pertanggungan jawab menurut hukum pidana yang dapat mengakibatkan pertanggungan jawab politik. ${ }^{23}$ Sedangkan "perbuatan tercela" adalah perbuatan yang dapat merendahkan martabat Presiden dan/atau Wakil Presiden. Meski telah disebutkan dan coba didefinisikan dalam ketentuan peraturan perundangundangan, kedua alasan impeachment tersebut masih memancing perdebatan wacana secara akademis yang dapat digali lebih dalam lagi.

Proses impeachment di Indonesia melalui proses di tiga lembaga negara secara langsung. Proses yang pertama berada di DPR (Dewan
Perwakilan Rakyat) dengan mengajukan usulan bahwa Presiden dan/atau Wakil Presiden telah melakukan pengkhianatan terhadap negara, atau penyuapan, atau tindak pidana berat lainnya, atupun perbuatan tercela bahkan DPR juga berwenang menyatakan bahwa Presiden dan/atau Wakil Presiden sudah tidak lagi memenuhi syarat sebagai pemimpin negara. DPR melalui hak pengawasannya melakukan proses investigasi atas dugaan-dugaan bahwa Presiden dan/atau Wakil Presiden melakukan tindakan-tindakan yang dapat dikategorikan sebagai tindakan yang tergolong dalam alasanalasan impeachment. Setelah proses di DPR selesai, dimana Rapat Paripurna DPR bersepakat untuk menyatakan bahwa Presiden dan/atau Wakil Presiden telah melakukan tindakan yang tergolong alasan untuk di-impeach maka putusan Rapat Paripurna DPR itu harus dibawa ke Mahkamah Konstitusi (MK). Sebelum akhirnya proses impeachment ditangani oleh Majelis Permusyawaratan Rakyat (MPR) untuk mendapat kata akhir sebagai penentu akan nasib Presiden dan/atau Wakil Presiden.

Jika MK berpendapat bahwa permohonan DPR mengenai dugaan pelanggaran tidak memenuhi ketentuan pasal 80 Undang-Undang Nomor 24 Tahun 2003 maka amar putusan MK menyatakan permohonan tidak dapat diterima. ${ }^{24}$ Namun sebaliknya, jika memenuhi ketentuan pasal 80 Undang-Undang Nomor 24 Tahun 2003 maka MK melakukan pemeriksaan terhadap perkara tersebut untuk kemudian memutuskan dengan amar putusan yang menyatakan membenarkan atau tidak membenarkan permohonan DPR atas dugaan pelanggaran oleh 
presiden/wakil presiden. ${ }^{25}$ Mekanisme ini sesuai dengan salah satu kewenangan konstitusional Mahkamah Konstitusi yaitu memutus pendapat DPR dalam proses impeachment presiden dan/ atau wakil presiden. ${ }^{26}$

Dalam praktik ketatanegaraan Indonesia, pembahasan terhadap alasan impeachment yang dituduhkan DPR adalah alasan yang berangkat dari sebuah proses politik dimana kepentingan-kepentingan yang lebih bermain untuk menghasilkan sebuah keputusan. Oleh karena itulah, perlu adanya sebuah lembaga negara yang memberikan legitimasi dalam perspektif yuridis dengan memberikan tafsiran atas tuduhan yang dijatuhkan kepada Presiden dan/atau Wakil Presiden tersebut. Lembaga konstitusional yang berwenang untuk memberikan tafsir yuridis atas tuduhan DPR tersebut adalah Mahkamah Konstitusi (MK). Pada posisi ini MK memiliki peranan yang sangat strategis karena MK adalah salah satu lembaga pemegang kekuasaan kehakiman dalam sistem peradilan dua atap di Indonesia sesuai amanat UUD 1945 perubahan. Akan tetapi pada proses impeachment ini MK tidak sedang mengadili Presiden dan/atau Wakil Presiden sebagai pribadi yang melakukan "tindak pidana". Tapi obyek sengketa yang menjadi fokus pemeriksaan MK adalah pendapat DPR atas kinerja Presiden dan/atau Wakil Presiden yang dianggap memenuhi Pasal 7A UUD 1945 perubahan. Kemudian, jika terdapat pengadilan yang memeriksa Presiden dan/atau Wakil Presiden yang telah diberhentikan atas tuduhan melakukan pelanggaran hukum, maka pengadilan tersebut tetap memiliki kewenangan untuk melakukannya dan tidak bertentangan dangan asas nebis in idem dalam konteks Hukum Pidana maupun Hukum Acara Pidana. Karena pengadilan tersebut mengadili Presiden dan/ atau Wakil Presiden dalam kapasitasnya yang berlangsung ketika digelar persidangan di MK adalah dalam kerangka peradilan tata negara. Sehingga MK tidak memiliki kewenangan untuk menjatuhkan putusan yang berupa sanksi pidana. Hanya jika putusan yang dijatuhkan MK adalah "membenarkan pendapat DPR" maka DPR dapat melanjutkan proses impeachment ke MPR. Suara terbanyak anggota MPR sesuai dengan prosedur yang diatur dalam Pasal 7B ayat (7) UUD 1945 perubahan yang akan menjadi kata akhir dalam persoalan impeachment di Indonesia. ${ }^{27}$ Putusan MPR sah dengan persetujuan sekurang-kurangnya 2/3 anggota MPR dalam rapat paripurna yang dihadiri minimum 3/4 dari jumlah anggota MPR. Hal ini menunjukkan bahwa proses pemakzulan presiden tidaklah mudah, bahkan dari sudut pandang politik, proses pemakzulan presiden didesain menjadi sangat sulit karena harus mendapat persetujuan mayoritas mutlak.

\section{Pengaturan Pemakzulan dalam konstitusi sebagai penegasan bentuk negara hukum}

Indonesia merupakan negara yang menganut sistem pemerintahan presidensial. Hal ini meskipun tidak secara tegas dinyatakan

25 Pasal 83 Ayat (2) dan ayat (3) Undang-Undang Nomor 24 Tahun 2003 Tentang Mahkamah Konstitusi.

26 Ikhsan Rosyada Parluhutan Daulay, Mahkamah Konstitusi Memahami Keberadaannya Dalam Sistem Ketatanegaraaan Republik Indonesia (Jakarta: PT Rineka Cipta, 2006).

27 Yudho Winarno. dkk. Mekanisme Impeachment dan Hukum Acara Mahkamah Konstitusi (Jakarta: Pusat Penelitian dan Pengkajian Mahkamah Konstitusi, 2005). 
dalam UUD 1945, namun dapat diidentifikasi dari pasal-pasal dalam UUD yang mengandung ciri sistem pemerintahan presidensial. Sistem pemerintahan ini menghendaki terwujudnya suatu pemerintahan yang stabil, karena Presiden tidak dapat dengan mudah dijatuhkan, dan dimakzulkan oleh parlemen. Hal ini berbeda dengan apa yang terjadi saat pemakzulan presiden dalam era UUD 1945 sebelum perubahan yang tidak mengatur secara khusus mengenai mekanisme pemberhentian presiden. Ketika itu, Presiden dapat diberhentikan jika pertanggungjawabannya tidak diterima oleh Majelis Permusyawaratan Rakyat (MPR). Mekanisme semacam ini jelas sangat kontradiktif dengan sistem presidensial yang menghendaki terjaminnya stabilitas pemerintahan, bahkan praktik seperti itu cenderung menyerupai karakteristik sistem pemerintahan parlementer.

Namun prinsip dalam menghendaki terwujudnya pemerintahan yang stabil bukan pula diartikan bahwa Presiden sebagai eksekutif memiliki kekuasaan absolut dan tidak terbatas, harus selalu ada mekanisme untuk melakukan kontrol serta check and balances, mekanisme yang dimaksud tentu harus sesuai pula dengan semangat negara hukum, yang diimplementasikan dalam sebuah peradilan merdeka dan berwibawa serta semata-mata menegakkan hukum, maka disinilah Mahkamah Konstitusi berperan dalam salah satu tahap mekanisme pemakzulan presiden sesuai dengan kewenangan yang diatur oleh konstitusi dan undang-undang. Selain itu, alasan-alasan yang membuat seorang presiden menghadapi konsekuensi hukum pun tentunya haruslah alasan-alasan hukum seperti apa yang telah ditentukan oleh pasal 7A UUD 1945 hasil perubahan ketiga. Melalui perubahan ketiga pula, terlihat suatu penegasan sebagaimana ditegaskan dalam Pasal 1 ayat (3) UUD Negara Republik Indonesia Tahun 1945, bahwa Indonesia adalah negara hukum, bahwa segala pelanggaran hukum akan mengahadapi konsekuensi hukum, termasuk seorang presiden sekalipun yang dapat diberhentikan dari jabatannya, namun jika melihat proses dan mekanismenya tentu saja pemberhentian presiden ini dibuat sedemikian rupa sehingga tidak mudah dilakukan, hal ini selaras dengan sistem presidensial yang menghendaki terwujudnya suatu pemerintahan yang stabil.

Sebagaimana diuraikan sebelumnya, bahwa mekanisme pemberhentian presiden yang diatur dalam konstitusi adalah penegasan bahwa Republik Indonesia adalah negara hukum, ini adalah suatu langkah maju dalam perspektif ketatanegaraan agar pemakzulan presiden yang didasari faktor non yuridis semata tak terjadi kembali dimasa yang akan datang. Namun di lain sisi, prinsip negara hukum yang menghendaki suatu kekuasaan peradilan yang merdeka, yang tidak dipengaruhi oleh kekuatan-kekuatan lain yang akan menyimpangkan hakim dari kewajiban menegakkan hukum, keadilan, dan kebenaran serta semangat untuk menjadikan hukum sebagai putusan akhir yang berwibawa dan dihormati seolah dikesampingkan dalam mekanisme pemberhentian presiden sebagaimana diatur dalam Pasal 7A sampai Pasal 7B ayat (7) UUD 1945, karena dalam mekanisme impeachment, putusan Mahkamah Konstitusi yang membenarkan pendapat DPR tidak bersifat mengikat. Dalam tahapan selanjutnya putusan ini dapat saja tidak disepakati dan dianggap angin lalu oleh suara mayoritas di MPR. Terlebih tidak ada satu pun ketentuan dalam konstitusi maupun peraturan perundang-undangan lain yang mengatur secara eksplisit kekuatan putusan Mahkamah Konstitusi dalam hal ini. 
Ditambah lagi dengan masih diberikannya kesempatan kepada Presiden dan/atau Wakil Presiden menyampaikan penjelasan dalam sidang paripurna di MPR. Artinya, putusan hukum dapat saja "dikalahkan" oleh putusan politik. Adapun penulis berpendapat bahwa konsistensi sebagai negara hukum akan lebih terwujud bilamana proses akhir dalam rapat paripurna MPR adalah bersifat menguatkan putusan Mahkamah Konstitusi.

\section{E. Penutup}

Mekanisme pemakzulan presiden yang berlaku saat ini adalah bentuk nyata korelasi antara proses hukum dan proses politik dalam praktik ketatanegaraan. Proses tersebut diawali dengan proses politik di DPR yang berlanjut dengan proses hukum di MK, kemudian kembali memasuki proses politik saat memasuki mekanisme final di MPR. Begitupun dengan alasan-alasan pemakzulan, kini tak hanya berdasarkan faktor politis dan kebijakan semata yang menjadi domain lembaga politik (MPR dan DPR) seperti dimasa lalu, namun juga harus berdasarkan alasan pelanggaran hukum yang diuji secara yuridis oleh Mahkamah Konstitusi (MK). Pengaturan proses dan mekanisme pemakzulan dalam konstitusi dapat dikatakan sebagai suatu langkah maju karena telah mengedepankan prinsip-prinsip negara hukum dan demokrasi. UUD 1945 pasca amandemen membuat pemakzulan presiden menjadi lebih sulit dan itu sejalan dengan semangat untuk memperkuat sistem presidensial. Langkah maju ini tentunya harus dipertahankan jika kita ingin konsisten dengan prinsip negara hukum yang dicita-citakan.

Meski demikian, aspek substansi dan mekanisme terkait pemakzulan yang kini sudah jauh lebih baik dengan pengaturan yang lebih jelas dan lengkap, kiranya tetap perlu terus dikaji secara dialektika akademis, utamanya terkait mengenai peran dari MPR dalam putusan akhir proses pemakzulan, apakah tetap dengan putusan yang dapat bertolak belakang dengan putusan hukum MK, karena penulis berpendapat putusan terkuat, yang bersifat akhir dan mengikat adalah putusan hukum yang dikeluarkan oleh proses peradilan hukum di MK, sehingga rapat paripurna MPR seharusnya hanya bersifat menguatkan dan menegaskan secara kenegaraan putusan MK.

\section{DAFTAR PUSTAKA}

\section{Buku}

Asshiddiqie, Jimly, Pokok-Pokok Hukum Tata Negara Indonesia Pasca Reformasi (Jakarta: Buana IImu Populer, 2007).

Budiarjo, Miriam, Dasar-Dasar Ilmu Politik (Jakarta: PT. Gramedia Pustaka Utama, 1993).

Daulay, Ikhsan Rosyada Parluhutan, Mahkamah Konstitusi Memahami Keberadaannya Dalam Sistem Ketatanegaraaan Republik Indonesia (Jakarta: PT Rineka Cipta, 2006).

Indrayana, Denny, Negara Antara Ada dan TiadaReformasi Hukum Ketatanegaraan (Jakarta: Kompas Media Nusantara, 2008).

Kusnardi, Moh., dan Hamaily Ibrahim, Hukum Tata Negara Indonesia (Jakarta: Pusat Studi Hukum TataNegara FH UI, 1976).

Mahfud M.D., Moh., Dasar dan Struktur Ketatanegaraan Indonesia (Yogyakarta: Universitas Islam Indonesia Press, 1993).

Manan, Bagir, Lembaga Kepresidenan (Yogyakarta: Gama Media, 1999).

Manan, Bagir, Teori dan Politik Konstitusi (Yogyakarta: FH-UII PRESS, 2004).

Martosoewignjo, Sri Soemantri, Pengantar Perbandingan Antar Hukum Tata Negara (Jakarta: CV Rajawali, 1981).

Martosoewignjo, Sri Soemantri, Prosedur dan Sistem Perubahan Konstitusi, edisi revisi (Bandung: Alumni, 2006).

Strong, CF., Modern Political Constitutions (London: Sidgwick, 1960). 
Tempo, Sukarno-Paradoks Revolusi Indonesia, Seri Buku Tempo (Jakarta: Kepustakaan Populer Gramedia, 2010).

Wheare, K.C., Modern Constitution (London: Oxford University Press, 1975).

Winarno, Yudho. dkk., Mekanisme Impeachment dan Hukum Acara Mahkamah Konstitusi (Jakarta: Pusat Penelitian dan Pengkajian Mahkamah Konstitusi, Jakarta, 2005).
Zoelva, Hamdan, Pemakzulan Presiden di Indonesia (Jakarta: Sinar Grafika, 2011).

\section{Peraturan}

UUD 1945 (sebelum dan sesudah perubahan) Undang-Undang Nomor 24 Tahun 2003 Tentang Mahkamah Konstitusi 